\title{
Syrphids in Integrated Control of Aphids
}

\author{
Maria Ángeles Marcos García and Eduardo Galante Patiño*
}

Research Institute CIBIO (Centro Iberoamericano de la Biodiversidad), Unidad Asociada IPAB (UA-CSIC) University of Alicante, Spain

ISSN: 2637-7659

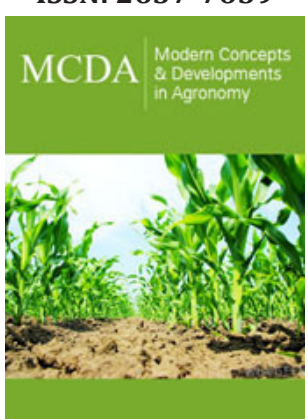

*Corresponding author: Eduardo Galante Patiño, Research Institute CIBIO (Centro Iberoamericano de la Biodiversidad), University of Alicante, 03690 San Vicente del Raspeig, Alicante, Spain

Submission: 侮July 24, 2021

Published: 監August 05, 2021

Volume 9 - Issue 2

How to cite this article: Maria Ángeles Marcos García, Eduardo Galante Patiño. Syrphids in Integrated Control of Aphids. Mod Concep Dev Agrono. 9(2). MCDA. 000708. 2021. DOI: 10.31031/MCDA.2021.09.000708

Copyright@ Eduardo Galante Patiño. This article is distributed under the terms of the Creative Commons Attribution 4.0 International License, which permits unrestricted use and redistribution provided that the original author and source are credited.

\begin{abstract}
This paper focuses on the role of aphidophagous syrphids in different strategies of Integrated Pest Control in greenhouse crops. Southeastern Spain is the world area with the highest production of organic products. Our scientific experience and field experimentation in the use of syrphids for control of pest aphids, show compatibility and effectiveness on the combined use of syrphids with other strategies commonly used in integrated pest control.
\end{abstract}

\section{Introduction}

'Flower flies' is a vernacular name for syrphids (Diptera, Syrphidae), which are known to be frequent visitors of flowers, where they obtain their feeding resource from (i.e. pollen and nectar). This behavior makes that these flies are now regarded as one of the main pollinator groups within insects [1]. In addition, their larvae are predatory, mycophagous, phytophagous or saprophagous (Sommaggio, 1999). The present paper focuses on the species with predatory larvae, which represent over a third of the $6200+$ syrphid species known worldwide. The larvae of these species prey on small soft-bodied insects [2], especially aphids (Homoptera, Aphididae), which may cause severe damage mainly in greenhouse crops.

Erasmus, Charles Darwin's grandfather (1731-1802), already recognized the predatory potential of syrphids when stating that "The most ingenious manner of destroying the aphids would be affected by the propagation of its greatest enemy, the larva of the aphidivorous hoverflies". However, and due to its crypsis, low visibility in the field and their nocturnal activity, the use of these larvae in aphid pest control has not been developed until recent times. Episyrphus balteatus (De Geer, 1776), was the first syrphid used commercially in biological control of aphids well inside the $20^{\text {th }}$ century, after its potential as a predatory agent of pest aphids was empirically confirmed [3]. More recently, in 2016, Sphaerophoria rueppellii (Wiedemann, 1820) was released in the market as a new product for control of pest aphids by BioNostrum Pest Control, which, by then, was a 'spin off' company at the University of Alicante (Spain).

\section{Why syrphids?}

The effectiveness of hoverflies in the control of aphids has been well demonstrated scientifically and relies on the following facts:

a) They act like natural drones, because females lay eggs in situ, among the aphid colonies.

b) Early and dense-dependent oviposition. This allows preventive and curative treatments, as well as avoiding intraspecific competition.

c) Long permanence of the syrphids in crops due to their polyvoltine cycles.

d) Larvae prey on a wide range of aphid species.

e) Larvae are stealthy, reducing the possibility of aphids to escape. 


\section{Syrphids in the aphid control in greenhouse crops}

Southeastern Spain is the world area with the highest production of organic products. We present here a summary of our scientific and applied experience in the use of syrphids for biological control of pest aphids in Mediterranean greenhouse crops, as well as the results of their combined use with other strategies commonly used in integrated pest control (Figure 1).

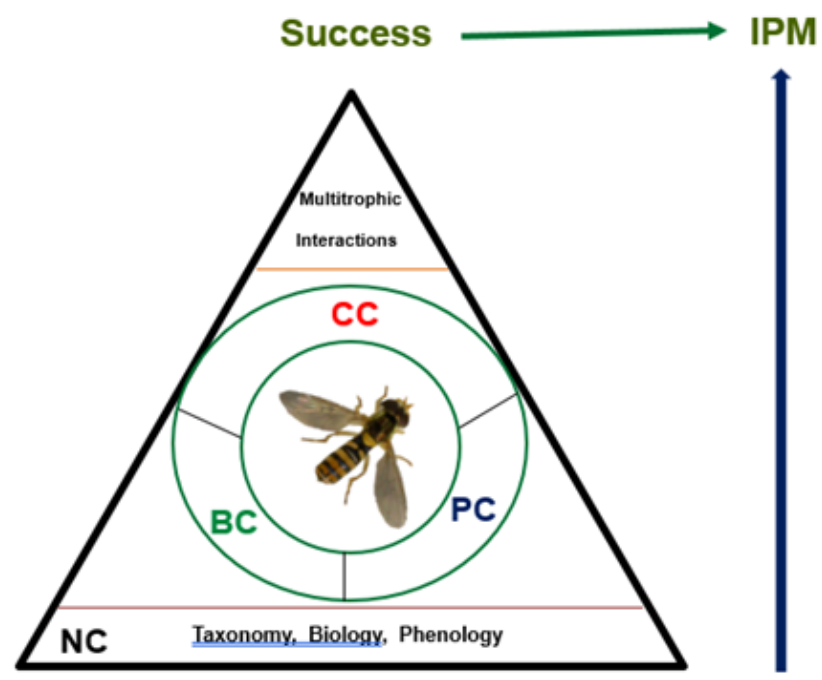

Figure 1: Control strategies in which syrphids are involved. PC: Parabiological Control, BC: Biological Control, CQ: Chemical Control, CN: Natural Control, IPM: Integrated Pest Management.

The interior of Mediterranean greenhouses has high levels of temperature $\left(+40^{\circ} \mathrm{C}\right)$ and humidity $(+85-90 \%)$. Only some insect species are adapted to survive in these extreme environmental conditions. We have recorded more than ten species of aphidophagous syrphids inside the greenhouses of this geographic area of Spain [4], but only E. balteatus, Eupeodes corollae (Fabricius, 1794) and S. rueppellii were found not to be sporadic, i.e. they were installed indoors feeding on pest aphids [5]. Of those three, $S$. rueppellii was found to remain indoors during the entire crop cycle while supporting well the harsh greenhouse conditions [6].

\section{Hoverflies in the control of aphid pest of greenhouse crops}

Synergy of the use of syrphids with parasitoids: The control of a pest does not depend exclusively on a single natural enemy, so it is important to know the level of compatibility of syrphids and the parasitoids commonly used for aphid control in greenhouses. Results showed a positive intragremial relationship with Aphidius colemani (Dalman, 1820) by rejecting the syrphid females, ovipositing in colonies where the aphid was mummified [7] and rejecting the larvae to feed on parasitized aphids. Thus, the biological control with syrphids is complementary to the use of parasitoids (Hymenoptera, Braconidae).

Compatibility with reservoir plants (Banker Plants): During tests with syrphids in pepper greenhouses, we observed syrphid eggs in the barley plants used by farmers as a reservoir of aphids for parasitoids. We evaluated the effect of reservoir plants infested with the aphid Rhopalosiphum padi (Linnaeus, 1758) on the enhancement of predatory syrphid populations inside greenhouses. The prolongation of the residence time of the adult syrphids released inside was also evaluated [8]. Results showed that the presence in the greenhouse of adult syrphids and their immature stages (larvae and pupae) on crop plants increased significantly inside greenhouses with presence of Banker Plants.

Syrphids and flowers (Biological Control by Conservation): Adult syrphids need pollen and nectar for two crucial biological functions. Pollen is required for sexual maturation and nectar is the main source of energy for sustaining their characteristic and skilled hovering flight [9]. Moreover, flowers are the places where males and females usually meet for mating. Our studies confirmed that the provision of pollen and nectar by flowering plants placed inside greenhouses, increased the abundance of syrphids, both as larvae and adults. The residence time of the adults in the greenhouse exceeded that required for the females to mature and oviposit in the aphid colonies before leaving the greenhouse. For all these reasons, we proposed for the first time the convenience of planting Lobularia maritima L. Desv. and Coriandrum sativum L. inside the greenhouse [10], which has become a common practice nowadays. Adult syrphids also contribute to crop pollination in greenhouses [11].

\section{Hoverflies in para biological control strategies}

Syrphids and absorbers or supplementary ultraviolet light meshes: Photo selective meshes are ultraviolet light absorbers and have been shown to be effective for the control of pest aphids by limiting their dispersal ability. We studied the effect of these meshes on the behavior of aphidophagous syrphids in horticultural crops [12]. Experiments showed that the average number of syrphid eggs per plant and the abundance of syrphid larvae was remarkably higher under the photo selective meshes than under the standard coverage. The effect of supplementary UV radiation under glasshouse conditions was also studied, not affecting on the flight activity of adult syrphids [13], but showing that the use of these meshes, and the release of syrphid predators, are compatible strategies to be used in IPM aphid control programs.

\section{Hoverflies in chemical control}

Effect of toxicity, attraction or repellency of botanical insecticides in syrphids: With olfactometric techniques, we tested the effect on the behavior (attraction or repellency) of syrphid larvae against the use of VOCs from essential oils. Results showed that some repellents and aphidicide products, attract adults of the predatory syrphid $S$. rueppellii, which is the main natural enemy of two of the most harmful aphid species in greenhouses of pepper: Myzus persicae (Sulzer, 1776) and Macrosiphum euphorbiae Thomas, 1878 [14].

\section{Conclusion}

Investigation on Integrated Pest Management, considered globally as the paradigm for the crop protection in the future, 
requires not only the implementation of combined strategies, but integrated strategies [15]. In this summary, we present the results obtained after the integrated use of syrphids with other control strategies (biological, parabiological and chemical) for aphid control. The compatibility or synergy of these combinations have been tested in field or semi-field conditions, taking into account that the analyzed methods are commonly applied in Mediterranean greenhouses, where the greatest quantity of organic products in the world is produced.

\section{References}

1. Stefanescu C, Aguado LO, Asís JD, Baños Picón L, Cerdá X, et al. (2018) Diversidad de insectos polinizadores en la península ibérica. Ecosistemas 27(2): 9-22.

2. Rojo S, Gilbert F, Marcos García MA, Nieto JM, Mier Durante MP (2003) A world review of predatory hoverflies (Diptera, Syrphidae: Syrphinae) and their prey. CIBIO, Spain, p. 219.

3. Chambers RJ, Adams THL (1986) Quantification of the impact of hoverflies (Diptera, Syrphidae) on cereal aphids in winter wheat: an analysis of field populations. Journal of Applied Ecology 23(3): 895-904.

4. Quinto J, Marcos García MA, y Pineda A (2010) Comunidad de enemigos naturales de plagas de hemípteros en cultivos de pimiento de invernadero del sureste ibérico. Phytoma 224: 33-36.

5. Pineda A, Marcos García MA (2006) First data on the population dynamics of aphidophagous syrphids in Mediterranean pepper greenhouses. Integrated Control in protected Crops, Mediterranean Climate IOBC/wprs, 29(4): 169-174.

6. Amorós Jiménez R, Pineda A, Fereres A, Marcos García MA (2012) Prey availability and abiotic requirements of immature stages of the aphid predator Sphaerophoria rueppellii. Biological Control 63(1): 17-24.
7. Pineda A, Morales I, Marcos García MA, Fereres A (2007) Oviposition avoidance of parasitized aphids colonies by the syrphid predator Episyrphus balteatus mediated by different cues. Biological Control 42(3): 274-280.

8. Pineda A, Marcos García MA (2008a) Introducing barley as aphid reservoir in sweet-pepper greenhouses: Effect on native and released hoverflies (Diptera: Syrphidae). European Journal of Entomology 105(3): 531-535.

9. Rotheray GE, Gilbert F (2011) The natural history of hoverflies. Forrest Text (edn), UK, p. 334.

10. Pineda A, Marcos García MA (2008b) Use of selected flowering plants in greenhouses to enhance aphidophagous hoverfly populations (Diptera: Syrphidae). Annals de la Société Entomologique de France 44(4): 487492.

11. Pekas A, De Craecker I, Boonen S, Wäckers SL, Moerkens R (2020) One stone; two birds: concurrent pest control and pollination services provided by aphidophagous hoverflies. Biological Control 149: 104328.

12. Amorós Jiménez R, Plaza M, Monserrat M, Marcos García MA, Fereres A (2020) Effect of UV-Absorbing Nets on the Performance of the Predator Sphaerophoria rueppellii (Diptera: Syrphidae). Insects 11(3): 166.

13. Prieto Ruiz I, Garzo E, Moreno A, Dáder B, Medina P, Viñuela E, Fereres A (2019) Supplementary UV radiation on eggplants indirectly deters Bemisia tabaci settlement without altering the predatory orientation of their biological control agents Nesidiocoris tenuis and Sphaerophoria rueppellii. Journal of Pest Science 92(3): 1057-1070.

14. Cantó Tejero M, Casas JL, Marcos García MA, Pascual Villalobos MJ, Florencio Ortiz V, et al. (2021) Essential oils aphid (Myzus persicae and Macrosiphum euphorbiae) repellents. Journal of Pest Science 2: 971986.

15. Stenberg JA (2017) A conceptual framework for integrated pest management. Trends in Plant Science 22(9): 759-769.

For possible submissions Click below: 